\title{
ANALISIS KESALAHAN SISWA DALAM MENYELESAIKAN SOAL CERITA MATERI BARISAN DAN DERET ARITMATIKA
}

\author{
Tuti Handayani ${ }^{1}$, Hartatiana ${ }^{2}$, Muslimahayati $^{3}$ \\ Program Studi Pendidikan Matematika, Universitas Islam Negeri Raden Fatah Palembang 1,2,3 \\ e-mail: tutihandayani846@gmail.com
}

\begin{abstract}
ABSTRAK
Tujuan penelitian ini adalah untuk menganalisis kesalahan siswa dalam menyelesaikan soal cerita materi barisan dan deret aritmatika dan untuk mengetahui faktor internal penyebab siswa melakukan kesalahan dalam menyelesaikan soal cerita materi barisan dan deret aritmatika. Metode penelitian yang digunakan dalam penelitian ini adalah metode deskriptif dengan pendekatan kualitatif. Subjek penelitian terdiri dari 6 siswa. Data penelitian diperoleh dari tes tertulis, angket dan wawancara. Analisis data pada penelitian adalah analisis data kualitatif yang terdiri dari reduksi data, penyajian data, dan penarikan kesimpulan. Hasil penelitian diperoleh kesalahan yang dilakukan siswa yaitu kesalahan konsep, kesalahan menggunakan data, kesalahan interpretasi bahasa, kesalahan teknis dan kesalahan penarikan kesimpulan. Adapun penyebab kesalahan tersebut adalah karena kurangnya minat siswa dan kurangnya intelegensi siswa dalam menyelesaikan soal cerita materi barisan dan deret aritmatika.
\end{abstract}

Kata kunci :

Barisan dan deret aritmetika; Kesalahan siswa; Soal cerita.

\begin{abstract}
The purpose of this research was to analyze what were the students' error in completing the story matter sequences and arithmetic sequences and to determine the internal factors that cause students to make the error. The research method use in this research was a descriptive method with a qualitative approach. The subjects of the research consisted of 6 students. Research data obtained from written tests, questionnaires and interviews. Analysis of the data in the study was a qualitative data analysis consisting of data reduction, data display, and data verification. The results of the study obtained errors made by students namely concept errors, errors using data, errors in language interpretation, technical errors and conclusions. The cause of the error is due to the lack of student interest and the lack of student intelligence in solving the story matter of material sequence and arithmetic sequence.
\end{abstract}

Keywords:

Sequences and arithmetic sequences; Students error; Story problem.

\section{PENDAHULUAN}

UU No. 20 Tahun 2003 tentang Sistem Pendidikan Nasional menyatakan bahwa pendidikan adalah usaha sadar dan terencana untuk mewujudkan suasana belajar dan proses pembelajaran agar siswa secara aktif mengembangkan potensi dirinya untuk memiliki kekuatan spiritual keagamaan, pengendalian diri, kepribadian, kecerdasan, akhlak mulia, serta keterampilan yang diperlukan dirinya, masyarakat, bangsa dan Negara. Jadi, pendidikan merupakan upaya untuk membangun dan meningkatkan mutu peserta didik.

$$
\text { Tujuan utama mempelajari }
$$

matematika adalah dapat menemukan cara menyelesaikan soal (Budhi \& Kartasasmita, 2015). Menyelesaikan soal berarti menjawab pertanyaan dari soal tersebut dengan baik, dimulai dari memahami apa yang diketahui dari soal tersebut. Pelajaran matematika yang bermanfaat dalam kehidupan sehari-hari ini merupakan mata pelajaran yang masih ditakuti siswa. Siregar (2017) mengatakan bahwa matematika merupakan pelajaran 
yang sampai ini oleh para siswa masih dianggap sulit. Akibatnya banyak siswa yang melakukan kesalahan dalam menyelesaikan soal matematika yang berbentuk soal cerita.

Guru memiliki peran penting dalam menyelesaikan permasalahan tersebut. Guru perlu memahami kesalahankesalahan siswa dalam mengerjakan soal matematika untuk membantu siswa mengurangi kesalahan yang terjadi. Hal tersebut sejalan dengan penelitian (Sulis, 2018) yang menyatakan bahwa dalam kegiatan pembelajaran matematika biasanya siswa mengalami kesulitan ketika guru memberikan soal cerita. Terutama kesalahan menyelesaikan soal, salah satunya soal cerita. Manibuy (2014) mengatakan bahwa letak kesalahan didefinisikan sebagai bagian dari penyelesaian soal yang terjadi penyimpangan dalam mengerjakan soal.

Salah satu pembelajaran matematika yang dapat melatih dan mengembangkan kemampuan pemecahan masalah siswa adalah pembelajaran soal cerita (Rudtin, 2013). Soal cerita merupakan soal terapan dari pokok bahasan yang dihubungkan dengan kehidupan sehari-hari (Mumtahanah, 2018). Oleh sebab itu, kemampuan menyelesaikan soal cerita ini penting untuk meningkatkan kemampuan pemecahan masalah siswa.

Materi barisan dan deret aritmatika dalam bentuk soal cerita merupakan salah satu materi yang biasa siswa hadapi saat UN Matematika SMA/MA. Sehingga, penting untuk mengetahui kesalahan siswa dalam menyelesaikan soal cerita materi barisan dan deret aritmatika. Oleh sebab itu, peneliti tertarik membahas tentang "Analisis kesalahan siswa dalam menyelesaikan soal cerita materi barisan dan deret aritmatika pada siswa kelas XI MA Muhammadiyah 1 Palembang”.

\section{METODE PENELITIAN}

Jenis penelitian ini adalah deskriptif kualitatif yang dilaksanakan pada semester genap di MA Muhammadiyah 1 Palembang dengan tujuan untuk mengetahui kesalahan siswa dalam menyelesaikan soal cerita materi barisan dan deret aritmatika dan memperoleh informasi tentang faktor internal penyebab siswa melakukan kesalahan dalam menyelesaikan soal cerita materi barisan dan deret aritmatika. Subjek penelitian terdiri dari 6 siswa yaitu 2 siswa dari kemampuan tinggi, 2 siswa dari kemampuan sedang dan 2 siswa dari kemampuan rendah.

Teknik pengumpulan data yang digunakan adalah tes, wawancara dan angket dengan teknik pengolahan data yang terdiri atas reduksi data, display data dan analisis data. Peneliti menggunakan Soal cerita materi barisan dan deret aritmatika yang dibuat oleh Dosen dan Mahasiswa Universitas Ahmad Dahlan yaitu Sumargiyani \& Muhammad Iqna Hibatallah (2018) dengan penelitian yang berjudul Analisis Kemampuan Pemecahan Masalah Siswa Pada Materi Barisan dan Deret Siswa Kelas XI IPA MA ALI MAKSUM. Subjek penelitian terdiri dari 6 orang peserta didik yang dipilih berdasarkan teknik sampling purposive. Penelitian dilakukan dengan langkahlangkah menurut Satori \& Komariah (2017) yang terdiri atas 5 langkah, yakni memiih topik kajian, instrumentasi, pelaksanaan penelitian, pengolahan data dan hasil penelitian.

\section{HASIL DAN PEMBAHASAN}

Dari hasil penelitian yang telah dilakukan maka dapat diketahui kesalahankesalahan yang dilakukan oleh siswa dalam menyelesaikan soal cerita. Berikut penjelasan kesalahan-kesalahan yang dilakukan siswa dalam menyelesaikan soal. 
1) Kesalahan Konsep

Indikator kesalahan siswa dalam menyelesaikan soal cerita yang pertama adalah kesalahan konsep. Adapun deskriptor dari kesalahan konsep yaitu, siswa salah dalam menggunakan rumus untuk menyelesaikan soal.
Berikut jawaban siswa yang mengalami kesalahan konsep untuk soal nomor 2.

Soal nomor 2 :

Di antara nomor antrian 28 dan 52 disisipkan 9 nomor pengantri baru sehingga membentuk suatu barisan aritmatika. Berapa jumlah dari barisan tersebut?

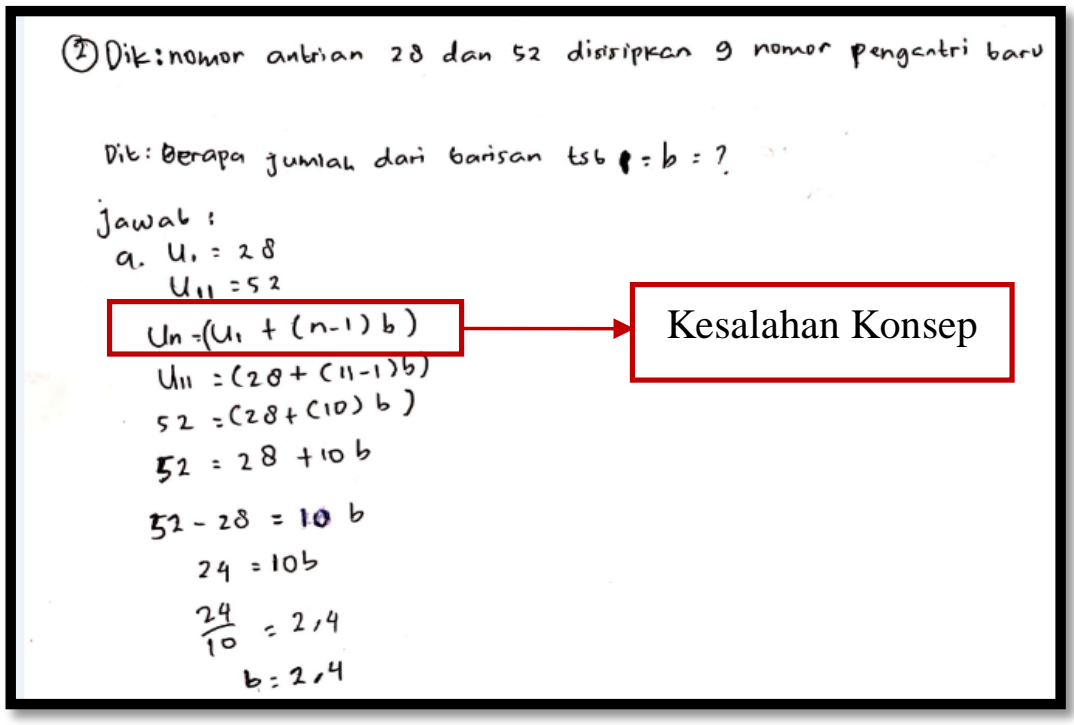

Gambar 1. Kesalahan Konsep

Gambar tersebut merupakan jawaban dari salah satu siswa yaitu S6 (siswa keenam). Dari jawaban tersebut terlihat bahwa S6 melakukan kesalahan konsep karena S6 tidak dapat menentukan rumus untuk menyelesaikan soal tersebut. Proses jawaban S6 sudah benar menggunakan rumus $U_{n}$ untuk mencari $b$ tetapi seharusnya setelah nilai $b$ didapat, S6 harus menggunakan rumus $S_{n}$ untuk menjawab jumlah dari barisan tersebut.

2) Kesalahan Menggunakan Data Indikator kesalahan siswa dalam menyelesaikan soal yang kedua adalah kesalahan menggunakan data. Adapun deskriptor dari kesalahan menggunakan data yaitu, siswa mengetahui data tetapi tidak menggunakan data atau tidak mensubstitusikan data kedalam rumus, siswa salah memasukkan data ke variabel, dan siswa menambah data yang tidak diperlukan dalam menyelesaikan soal.

Berikut jawaban siswa yang mengalami kesalahan menggunakan data untuk soal nomor 4.

Soal nomor 4 :

Dalam mempersiapkan pergelaran busana, seorang perancang busana melibatkan sebanyak 150 orang penjahit pakaian dari hari Senin sampai Sabtu. Agar lebih cepat selesai, setiap Minggu ditambah 6 orang penjahit. Setelah 12 minggu pekerjaan tersebut selesai. Berapa rupiah uang yang harus dikeluarkan oleh perancang busana tersebut jika upah penjahit Rp. 25.000,00 per hari? 


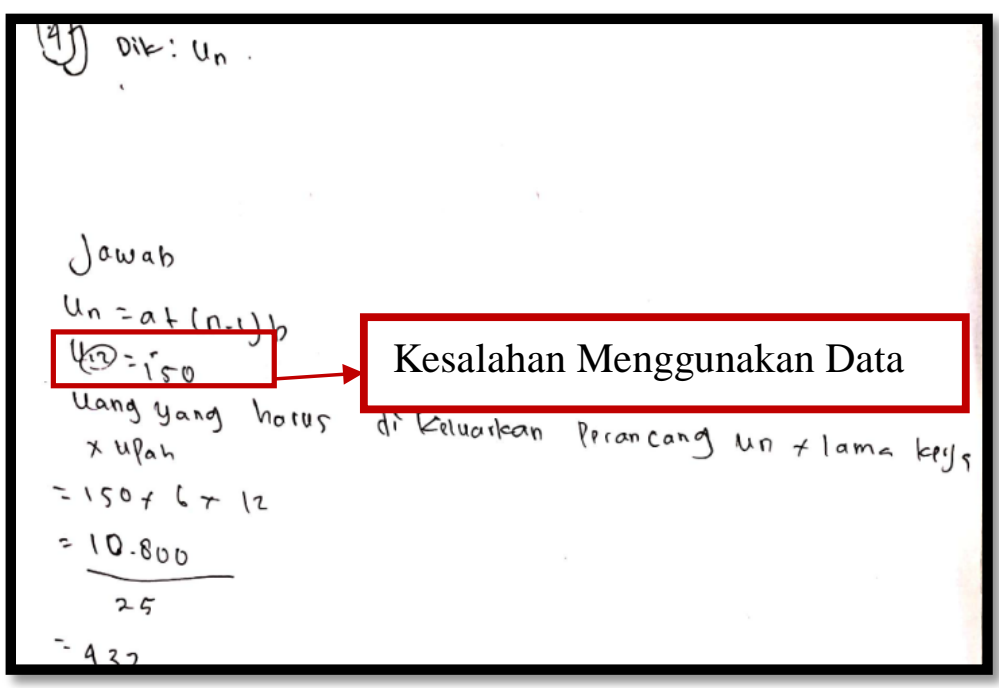

Gambar 2. Kesalahan Menggunakan Data

Gambar tersebut merupakan jawaban dari salah satu siswa yaitu S5 (siswa kelima). Dari jawaban tersebut terlihat bahwa S5 melakukan kesalahan menggunakan data karena S5 tidak mensubstitusikan nilai $b$, suku pertama dan nilai $n$ kedalam rumus. Akibat tidak menggunakan data S5 salah menghitung nilai $U_{n}$ tersebut.

3) Kesalahan Interpretasi Bahasa Indikator kesalahan siswa dalam menyelesaikan soal yang ketiga adalah kesalahan interpretasi bahasa. Adapun deskriptor dari kesalahan interpretasi bahasa yaitu, siswa salah dalam menyatakan bahasa sehari-hari dalam bahasa matematika dan siswa salah dalam mengintrepretasikan simbol-simbol, grafik dan tabel kedalam bahasa matematika.

Soal nomor 2 :

Di antara nomor antrian 28 dan 52 disisipkan 9 nomor pengantri baru sehingga membentuk suatu barisan aritmatika. Berapa jumlah dari barisan tersebut?

(2) Dik:nomor antrian 28 dan 52 disisipkan 9 nomor pengantri bard

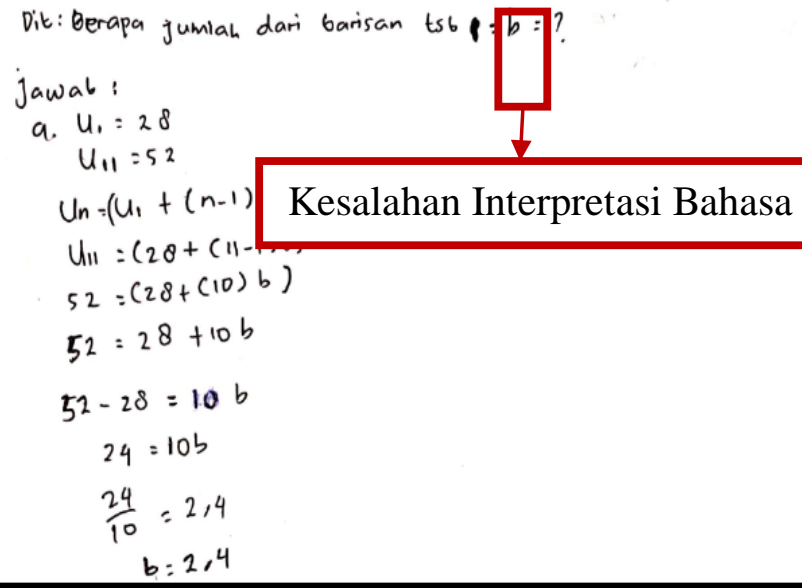

Gambar 3. Kesalahan Interpretasi Bahasa 
Gambar tersebut merupakan jawaban dari salah satu siswa yaitu S6 (siswa keenam). Dari jawaban tersebut terlihat bahwa S6 melakukan kesalahan interpretasi bahasa karena menyatakan jumlah dari barisan pengantri sebagai nilai beda. Seharusnya $S_{n}$.

4) Kesalahan Teknis

\begin{tabular}{lrr}
\multicolumn{2}{c}{ Indikator kesalahan siswa } \\
dalam menyelesaikan soal yang \\
keempat adalah kesalahan teknis. \\
Adapun deskriptor dari kesalahan \\
teknis yaitu, siswa salah dalam \\
melakukan penjumlahan atau \\
pengurangan atau perkalian atau
\end{tabular}

pembagian dan siswa salah dalam memanipulasi operasi aljabar.

Selanjutnya kesalahan yang S1 lakukan dalam menyelesaikan soal nomor 5 .

Soal nomor 5 :

Pak Tono dan Pak Soni menabung di Bank pada bulan pertama sebesar Rp. 200.000,00 dan Rp. 150.000,00, pada bulan selanjutnya masingmasing menabung sebesar Rp. 15.000,00 dan Rp. 25.000,00. Pada bulan ke berapa jumlah uang tabungan Pak Tono dan Pak Soni berjumlah sama?

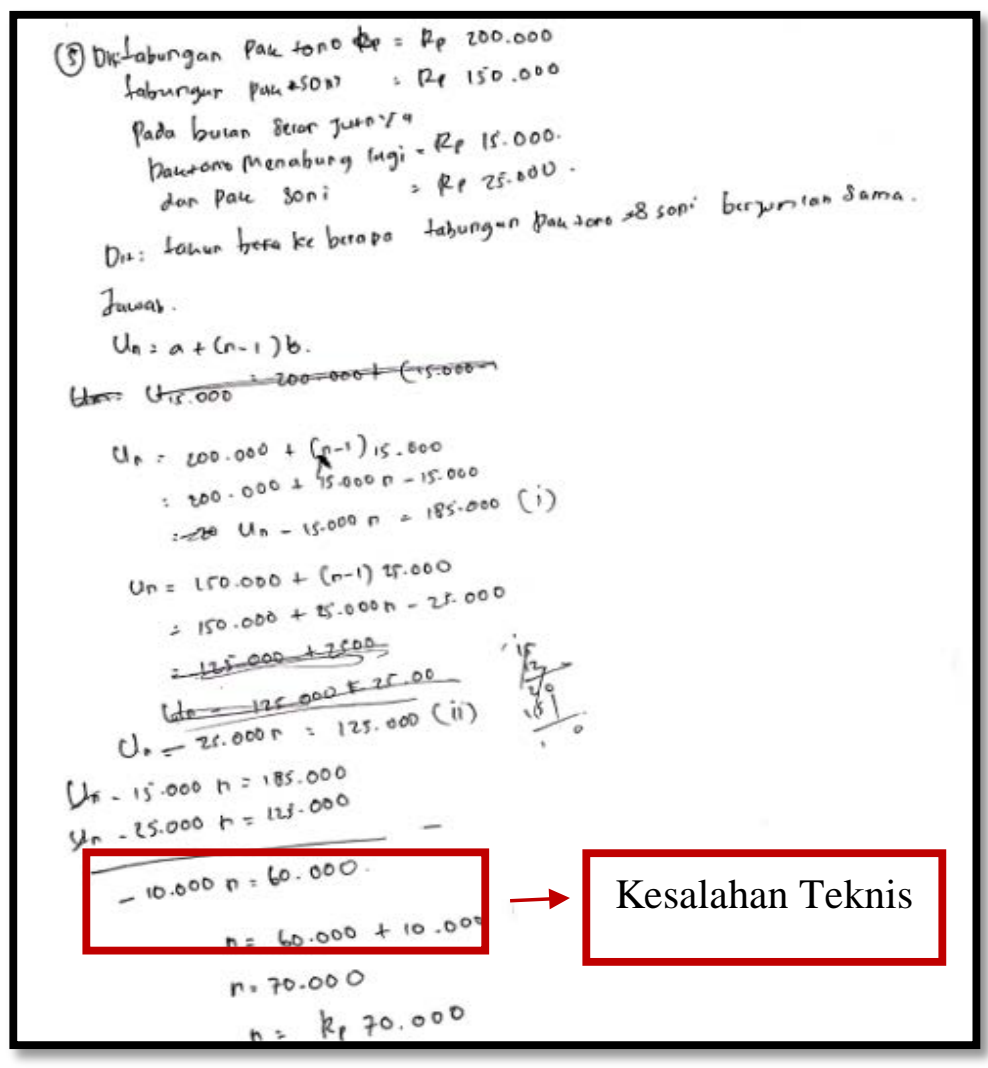

Gambar 4. Kesalahan Teknis

Gambar tersebut merupakan jawaban dari salah satu siswa yaitu S1 (siswa pertama). Dari jawaban tersebut terlihat bahwa S1 melakukan kesalahan teknis karena S1 melakukan kesalahan dalam memanipulasi operasi aljabar. Proses jawaban S1 sudah benar menggunakan rumus $U_{n}$ untuk mencari $\mathrm{n}$ tetapi seharusnya saat $10.000 n=60.000$ untuk mendapat nilai $n$, pindahkan saja 10.000 ke ruas kanan. Jadi, $n=\frac{60.000}{10.000}$,maka 
akan diperoleh $n=6$. Jadi, pada bulan ke-6 tabungan pak Tono dan pak Soni akan berjumlah sama.

5) Kesalahan Penarikan Kesimpulan

Indikator kesalahan siswa dalam menyelesaikan soal yang kelima adalah kesalahan penarikan kesimpulan. Adapun deskriptor dari kesalahan penarikan kesimpulan yaitu, siswa memberikan kesimpulan tanpa alasan pendukung yang benar dan siswa memberikan penyimpulan yang tidak sesuai dengan penalaran logis atau memberikan kesimpulan yang salah.

Soal nomor 3 : Sebuah perusahaan pakaian pada bulan ke-6 tahun 2017 memproduksi 275 pakaian/hari. Perusahaan tersebut merencanakan untuk menambah hasil produksinya secara tetap setiap bulan. Pada bulan ke-10 perusahaan tersebut memproduksi 335 pakaian/hari. Berapa kenaikan produksinya per bulan? (Anggap 1 bulan sama dengan 30 hari)

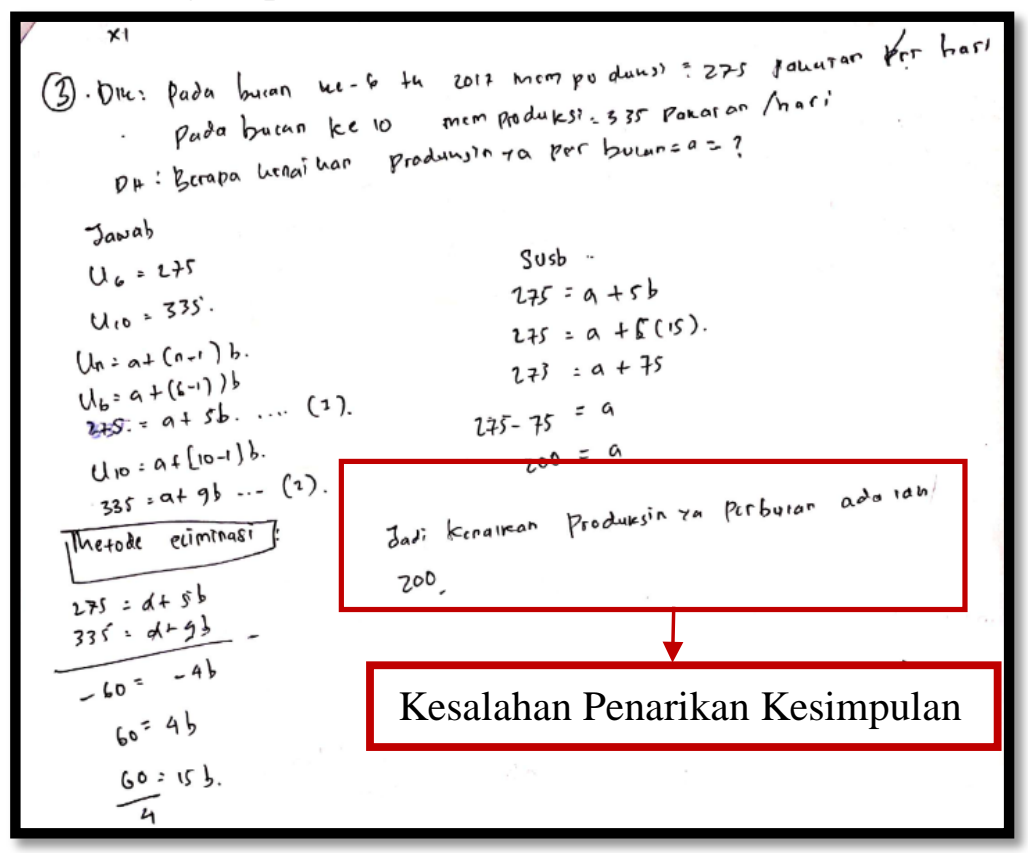

Gambar 5. Kesalahan Penarikan Kesimpulan

Gambar tersebut merupakan salah satu kesalahan penarikan kesimpulan yang dilakukan salah satu siswa yaitu
S1 (siswa pertama). Dari gambar tersebut terlihat bahwa S1 memberikan kesimpulan yang salah.

Tabel 1. Persentase Kesalahan Siswa Berdasarkan Jenis Kesalahan

\begin{tabular}{ccccccc}
\hline No. & \multicolumn{2}{c}{$\begin{array}{c}\text { Kesalahan } \\
\text { Konsep }\end{array}$} & \multicolumn{2}{c}{ Kesalahan Faktual } & \multicolumn{2}{c}{ Kesalahan Prosedural } \\
\cline { 3 - 7 } & Materi & $\begin{array}{c}\text { Kesalahan } \\
\text { Konsep }\end{array}$ & $\begin{array}{c}\text { Kesalahan } \\
\text { Menggunakan } \\
\text { Data }\end{array}$ & $\begin{array}{c}\text { Kesalahan } \\
\text { Interpretasi } \\
\text { Bahasa }\end{array}$ & $\begin{array}{c}\text { Kesalahan } \\
\text { Teknis }\end{array}$ & $\begin{array}{c}\text { Kesalahan } \\
\text { Penarikan } \\
\text { Kesimpulan }\end{array}$ \\
\hline 1. & D. Aritmatika & $44,44 \%$ & $0 \%$ & $29,63 \%$ & $14,81 \%$ & $3,70 \%$ \\
2. & D. Aritmatika & $55,55 \%$ & $7,40 \%$ & $40,74 \%$ & $25,92 \%$ & $3,70 \%$ \\
3. & Bar. Aritmatika & $14,81 \%$ & $3,70 \%$ & $3,70 \%$ & $48,15 \%$ & $3,70 \%$ \\
4. & Bar. Aritmatika & $18,51 \%$ & $40,74 \%$ & $11,11 \%$ & $0 \%$ & $0 \%$ \\
5. & Bar. Aritmatika & $18,51 \%$ & $0 \%$ & $14,81 \%$ & $55,55 \%$ & $11,11 \%$ \\
\hline
\end{tabular}

Keterangan :

$\mathrm{n}=27$ Siswa 
Hasil analisis data berdasarkan angket dan wawancara yang telah dilakukan dengan siswa menunjukkan bahwa, faktor internal penyebab siswa melakukan kesalahan dalam menyelesaikan soal cerita materi barisan dan deret aritmatika adalah sebagai berikut.

1) Minat

Persentase rata-rata jawaban
siswa pada angket terhadap indikator minat sebesar $33,45 \%$. Dari hasil analisis jawaban siswa pada angket dan wawancara hanya ada empat siswa atau $14,81 \%$ dari jumlah seluruh siswa yang selalu tertarik mempelajari dan mengerjakan soal cerita barisan dan deret aritmatika, ada 9 siswa atau 33,33\% yang suka mempelajari materi barisan dan deret aritmatika, hanya ada 6 siswa atau 22,22\% dari jumlah seluruh siswa kelas XI MA Muhammadiyah 1 Palembang yang fokus saat belajar materi barisan dan deret aritmatika, dan ada enam siswa atau 22,22\% siswa yang masih suka menyalin jawaban teman saat mengerjakan tugas yang diberikan guru. Terlihat hanya beberapa siswa yang minat. Minat mempunyai pengaruh yang besar terhadap belajar (Slameto, 2013). Jadi, minat siswa terhadap pembelajaran materi barisan dan deret aritmatika penting untuk ditingkatkan. Hal ini sejalan dengan pendapat Nuriyah (2015) yang mengatakan jika minat siswa terhadap pembelajaran rendah, maka dapat terjadi kesulitan dalam memahami materi yang berakibat terjadinya kesalahan-kesalahan yang dilakukan oleh siswa.

2) Motivasi

Persentase rata-rata jawaban
siswa pada angket terhadap

indikator motivasi sebesar 38,5\%. Kurangnya motivasi siswa terhadap pembelajaran dapat menyebabkan siswa melakukan kesalahan dalam menyelesaikan soal. Hal ini sejalan dengan pendapat Motivasi siswa yang rendah terhadap suatu mata pelajaran dapat menyebabkan siswa mengalami kesulitan yang berakibat terjadinya kesalahankesalahan yang dilakukan oleh siswa (Nuriyah, 2015). Dari hasil analisis jawaban siswa pada angket dan wawancara ada 16 siswa atau 59,25\% dari jumlah seluruh siswa yang selalu memperhatikan ketika guru menjelaskan, ada 7 siswa atau 25,92\% yang tidak pernah mengajak temannya bercerita pada saat pembelajaran, hanya ada sebelas siswa atau 40,74\% dari jumlah seluruh siswa kelas XI MA Muhammadiyah 1 Palembang yang berusaha mencapai tujuan pembelajaran, dan ada dua siswa atau $22,22 \%$ siswa yang tidak mengulang pelajaran saat dirumah. Terlihat hanya beberapa siswa yang memiliki motivasi terhadap pembelajaran matematika materi barisan dan deret aritmatika. Slameto (2013) mengatakan dalam proses belajar harus diperhatikan apa yang mendorong siswa agar dapat belajar dengan baik dan mempunyai motivasi untuk berpikir memusatkan perhatian terhadap pembelajaran.

3) Bakat

Persentase rata-rata jawaban siswa pada angket terhadap indikator bakat sebesar $38 \%$. Hanya ada dua siswa atau 7,40\% dari jumlah seluruh siswa yang selalu bisa menyelesaikan soal cerita materi deret aritmatika dengan tepat, ada 5 siswa atau $18,51 \%$ yang selalu menyelesaikan 
tugas dengan teliti dan dicek sampai jawaban benar. Terlihat hanya beberapa siswa yang memiliki bakat. Slameto (2013) mengatakan bakat itu mempengaruhi belajar dan jika bahan pelajaran yang dipelajari siswa sesuai dengan bakatnya, maka hasil belajarnya lebih baik karena dia akan senang belajar.

4) Intelegensi

Persentase rata-rata jawaban siswa pada angket terhadap indikator intelegensi sebesar $27,41 \%$. Hanya ada lima siswa atau $18,51 \%$ dari jumlah seluruh siswa yang bisa langsung menyelesaikan soal yang diberikan guru pada saat pembelajaran, ada 5 siswa atau $18,51 \%$ yang tidak memikirkan tugas yang diberikan guru, ada lima siswa atau 18,51\% yang selalu bertanya dengan guru jika ada yang tidak ia mengerti dalam pembelajaran, dan ada lima siswa juga yang selalu diam tidak bertanya dengan teman atau gurunya saat menemui kesulitan dalam pembelajaran. Jika intelegensi berupa kecakapan siswa serta pemahaman siswa terhadap materi masih kurang maka akan berdampak terjadinya kesalahankesalahan yang dilakukan oleh siswa dalam menyelesaikan soal (Nuriyah, 2015).

5) Faktor Kesehatan

Berdasarkan tabel diatas bahwa persentase rata-rata jawaban siswa pada angket terhadap indikator faktor kesehatan 40,75\%. Slameto (2013) mengatakan bahwa faktor kesehatan adalah keadaan baik segenap badan beserta bagianbagiannya bebas dari penyakit.

\section{SIMPULAN DAN SARAN}

Jenis-jenis kesalahan yang siswa lakukan dalam menyelesaikan soal cerita materi barisan dan deret aritmatika yaitu Kesalahan konsep terjadi sebesar 25,92\%, kesalahan menggunakan data terjadi sebesar 10,36\%, kesalahan interpretasi bahasa terjadi sebesar 19,99\%, kesalahan teknis terjadi sebesar 8,88\%, dan kesalahan penarikan kesimpulan terjadi sebesar 6,9\%.Faktor internal penyebab siswa melakukan kesalahan dalam menyelesaikan soal cerita materi barisan dan deret aritmatika adalah minat, bakat, motivasi, intelegensi dan faktor kesehatan. Faktor internal yang paling mempengaruhi siswa MA Muhammadiyah 1 Palembang dalam menyelesaikan soal cerita materi barisan dan deret aritmatika adalah intelegensi dan kurangnya minat terhadap pembelajaran.

Dari hasil kesimpulan tersebut saran yang dapat diberikan yaitu guru bisa menekankan pada penguasan konsep dengan memilih pembelajaran aktif yang membuat konsep bertahan lama dalam ingatan siswa, sehingga sifat siswa yang lupa dan bingung menggunakan rumus yang mana untuk menyelesaikan soal bisa diminimalisir, siswa harus banyak latihan mengerjakan soal matematika yang berbentuk soal cerita khususnya pada materi barisan dan deret aritmatika agar kesalahan konsep bisa diminimalisir dan pemahaman konsep siswa terhadap soal cerita materi barisan dan deret aritmatika meningkat. Siswa juga harus dilatih kemampuan berhitung untuk meminimalisir kesalahan teknis, dibiasakan untuk memeriksa kembali jawaban dengan cara memahami soal agar tidak terjadi kesalahan penarikan kesimpulan. Bagi peneliti selanjutnya, untuk mengetahui faktor penyebab siswa melakukan kesalahan dalam menyelesaikan soal diharapkan tidak hanya faktor internal saja tetapi juga faktor eksternal. 


\section{DAFTAR PUSTAKA}

Budhi, W. S., \& Kartasasmita, B. G. (2015). Berpikir Matematis (Matematika Untuk Semua). Jakarta: Erlangga.

Manibuy, R., Mardiyana, \& Saputro, D. R. (2014). Analisis Kesalahan Siswa dalam Menyelesaikan Soal Persamaan Kuadrat Berdasarkan Taksonomi Solo Pada Kelas X SMA Negeri 1 Plus Di Kabupaten Nabire. Jurnal Elektronik Pembelajaran Matematika , 2 (9), 933-945.

Mumtahanah, I. N. (2018). Kesalahan Siswa dalam Menyelesaikan Soal Cerita Pada Materi Sistem Persamaan Linear Dua Variabel (SPLDV) Berdasarkan Teori Polya Siswa Kelas VIII Sekolah Menengah Pertama. Surakarta: Universitas Negeri Surakarta. Diakses dari https://soo.gd/gN1A.

Nuriyah, F. E. (2015). Analisis Kesalahan Siswa dalam Menyelesaikan Soal Matematika Materi Pokok Persamaan dan Fungsi Kuadrat pada Siswa Kelas X MIA SMA Negeri 2 Wonosari. Universitas Negeri Yogyakarta.

Rudtin, N. A. (2013). Penerapan Langkah Polya dalam Model Problem Based Instruction Untuk Meningkatkan Kemampuan Siswa Menyelesaikan Soal Cerita Persegi Panjang. Jurnal Elektronik Pendidikan Matematika
Tadulako , 01 (01), 17-31. Diakses dari https://soo.gd/U7Qn.

Satori, D., \& Komariah, A. (2017). Metodologi Penelitian Kualitatif. Bandung: Alfabeta.

Siregar, N. R. (2017). Persepsi Siswa pada Pelajaran Matematika: studi Pendahuluan Pada Siswa yang Menyenangi Games. Prosiding Temu Ilmiah X Ikatan Psikologi Perkembangan Indonesia. Mahasiswa Universitas Gadja Mada Yogyakarta. (pp 224-232).

Sulis, M. K. (2018). Analisis Kesalahan dalam Menyelesaikan Soal Cerita Persamaan LinearSatu Variabel Berdasarkan Teori Polya Pada Siswa Kelas II SMP Muhammadiyah 7 Surakarta Tahun 2017/2018. Surakarta: Universitas Muhammadiyah Surakarta. Diakses dari https://soo.gd/nIc0.

Slameto. (2013). Belajar dan Faktorfaktor yang Mempengaruhi. Jakarta: Rineka Cipta.

Sumargiyani, \& Hibatallah, M. I. Analisis Kemampuan Pemecahan Masalah Siswa Pada Materi Barisan dan Deret Siswa Kelas XI IPA MA Ali Maksum. Prosiding Seminar Nasional Etnomatsia, (pp. 891900).

Undang-Undang Nomor 20 Tahun 2003 Tentang Sistem Pendidikan Nasional. 